\title{
Insecticidal Activity and Stability by Freeze-drying of Entomopathogenic Bacteria, Photorhabdus temperata M1021
}

\author{
Gun-Seok Park $\cdot$ Eun-Kyung Jang $\cdot$ Min-Sung Kim $\cdot$ Jae-Ho Shin
}

\section{동결건조에 따른 살충성 세균 Photorhabdus temperata M1021의 안정성과 살충성 평가}

박건석 · 장은경 · 김민성 · 신재호

Received: 12 January 2012 / Accepted: 30 April 2012 / Published Online: 30 June 2012

(C) The Korean Society for Applied Biological Chemistry 2012

\begin{abstract}
In order to develop eco-friendly biopesticide, an entomopathogenic bacterium Photorhabdus temperata M1021 has been lyophilized via freeze-drying along with protective agents such as skim milk, starch, sodium alginate, glucose and sodium glutamate to protect cells from lysis. Freeze-drying powder of $P$. temperata M1021 containing 7\% skim milk (w/v) showed highest survival rate of $63 \%$ among all the protective agents used in trials. Furthermore, the freeze-dried microbial powder showed $75 \%$ of survival rate after stored at $4^{\circ} \mathrm{C}$ for 4 weeks at air contact conditions. Injection toxicity of the freeze-dried sample was tested against larvae of Galleria mellonella. A dose of $2.0 \times 10^{1}$ cells of P. temperata M1021 killed $100 \%$ of the G. mellonella larvae within 4 days after injection. Moreover, $2.0 \times 10^{0}$ cells caused $50 \%$ mortality within the 4 days after injection. Freeze-dried $P$. temperata M1021 strains exhibited effective insecticidal activity and could be a better candidate for being used as a biopesticide.
\end{abstract}

Keywords biopesticide $\cdot$ freeze-drying Photorhabdus . skim milk

G.-S. Park $\cdot$ E.-K. Jang $\cdot$ M.-S. Kim $\cdot$ J.-H. Shin $(\bowtie)$

School of Applied Bioscience, Kyungpook National University, Daegu 702-701, Republic of Korea

E-mail: jhshin@knu.ac.kr

E.-K. Jang

Food and biological resources examination division, Korean intellectual property office, Daejeon 302-701, Republic of Korea
서 론

Photorhabdus 속 세균은 Xenorhabdus 속 세균과 더불어 곤충 에게 독성을 나타내는 곤충병원성 선충의 장내에 공생하는 공 생균으로 여러 종류의 살충단백질과 독성물질을 분비하여 직접 적으로 곤충의 생장을 저해하거나 사멸시키는 것으로 알려져 있 다(Daborn et al., 2002; Ji and Kim, 2004; Brugirard-Ricaud et al., 2005). 현재, 이러한 선충과 공생균으로 이루어진 공생체는 부가가치가 높은 작물의 생물학적 해충방제제로 제품화되어 판 매되고 있으며, 해충의 방제에 매우 효과적이다(Kaya and Gaugler, 1993; Ehlers, 2001; Kaya et al., 2006). 그러나 공생 세균을 함유한 선충의 생산 및 제품화는 선충의 저장 안정성, 감염능의 저하 및 오염 등의 문제로 품질의 저하가 우려된다 (Zhao et al., 2003; Wang et al., 2007). 곤충 병원성 선충의 공 생세균의 일종인 Xenorhabdus 속 세균은 숙주선충인 Steinernema 속과 같이 곤충에 침투할 경우에만 높은 병원성을 나타내며(반 수치사량, $\mathrm{LD}_{50}<100$ cells), 공생균만으로는 병원성이 매우 낮 아진다( $\mathrm{LD}_{50}>5,000$ cells). 그러나 Photorhabdus 속 세균은 숙 주선충인 Heterorhabditis가 없더라도 꿀벌 부채명나방 유충에 대한 $\mathrm{LD}_{50}$ 수치가 100 cells 이하로 병원성이 매우 높으며, 나 비목, 개미목과 모기 등에 대한 경구독성이 있는 것으로 알려 져 있다(ffrench-Constant and Bowent 1999; Dong Woon et al., 2002; Blackburn et al., 2005).

공생세균 자체로 높은 병원성을 가지는 Photorhabdus 속 세 균을 미생물농약 소재로 직접 개발하기 위해서는 산업화에 적 합한 제형을 가지는 제제화 실험이 필수적이다. 미생물농약의 안정화를 위한 제제화 기술로는 크게 기능성 고분자 및 다당류 로 캡슐화시키는 방법과 세포보호제를 첨가하여 동결건조하는 방법이 주로 이용되고 있다(Bozolu et al., 1987; Zhao and Zhang 2005; Tao et al., 2009). 동결 건조시에는 온도와 수분의 
손실을 최소화하기 위하여 skim milk, starch, dextran, polyvinylpyrrolidone (PVP)와 같은 고분자 물질과 glucose, sucrose, lactose, sodium glutamate 등과 같은 저분자 물질 등이 이용된 다(Theunissen et al., 1993; Wolfe and Bryant, 1999). 현재까 지 진행된 Photorhabdus 속 세균의 제제화실험은 sodium alginate bead 내에 P. luminescens 배양균체를 캡슐화시킨 제제 가 담배거세미나방(Spodoptera litura) 유충에 대한 구강 독성활 성이 있다고 보고되어 있으나(Bashan et al., 2002; Rajagopal et al., 2006; Power et al., 2011) 보존제의 종류, 보존기간에 따른 균의 생존율과 살충력 등은 보고되어 있지않다.

본 연구에서는 동결건조에 따른 공생세균의 생존율과 동결건 조 시에 첨가되는 sodium alginate, starch, skim milk, glucose, sodium glutamate와 같은 보존제의 첨가 및 농도에 따른 균의 생존율을 확인하였다. 최종적으로 동결 건조된 분말의 꿀벌 부 채명나방 유충에 대한 주사독성실험을 수행함과 동시에 보관기 간에 따른 균주의 안정성을 확인하였다.

\section{재료 및 방법}

사용 균주 및 배양조건. 본실험에 사용된 Photorhabdus temperata M1021 (KACC 91627P)은 곤충병원성 선충에서 분 리한 높은 활성의 곤충병원성 공생세균으로 Photorhabdus 균주 는 TSB agar 배지를 이용하여 $28^{\circ} \mathrm{C}$ 에서 48 시간 배양하여 사용 하였다.

재료 및 시약. 동결건조 시 사용된 보존제인 skim milk, starch, sodium alginate, glucose, sodium-glutamate 등은 Sigma-Aldrich Co. (USA)에서 구입하여 사용하였다. Photorhabdus 균주의 배 양용 배지인 trypticsoy broth (TSB)는 Becton, Dickinson and Company (USA)에서 구입하여 사용하였고, 기타 시약은 각 제 조사의 특급시약을 사용하였다.

동결건조 시료의 제조. 동결건조에 사용할 균체는 본배양에서 48 시간 배양한 P. temperata M1021의 배양액을 $4^{\circ} \mathrm{C}$ 에서 $10,000 \mathrm{rpm}$ 의 속도로 20 분간 원심분리하여 균체를 회수한뒤 $0.85 \%$ 의 멸균 생리식염수에 1 회 세척한 후 동일한 식염수에 현 탁하였다. 동결건조 시 균체의 생존율에 영향을 미치는 보존제 의 효과를 확인하기 위하여, skim milk, starch, sodium glutamate 는 각각 $15 \%(\mathrm{w} / \mathrm{v})$ 농도로 제조하였으며, 점성이 높아 고농도 의 실험이 어려운 sodium alginate는 $4 \%(\mathrm{w} / \mathrm{v})$, glucose의 경 우 $2 \%(\mathrm{w} / \mathrm{v})$ 농도로 제조하여 사용하였다. 균체 현탁액에 첨가 하는 보존제의 최종농도가 starch와 sodium glutamate는 각각 $1,3,5,7 \%(\mathrm{w} / \mathrm{v})$, skim milk는 1, 5, 7, 10\% (w/v), glucose 는 $0.5,1 \%(\mathrm{w} / \mathrm{v})$, sodium alginate는 $0.5,1,1.5 \%(\mathrm{w} / \mathrm{v})$ 농 도가 되게 각각 첨가하였다. 각각의 보존제를 첨가하여 균일하 게 혼합한 다음 $-70^{\circ} \mathrm{C}$ 에서 완전히 동결한 후, 동결건조기 (LABCONCO, USA)를 사용하여 3일간 동결건조 하였다. 동결 건조가 완료된 시료는 시료의 무게를 측정한 다음 균일하게 분 쇄하여 $4^{\circ} \mathrm{C}$ 에서 냉장 보관하였다.

동결건조 처리 후 균의 생존율 조사. 각 보존제 종류 및 농도 에 따른 균의 생존율을 알아보기 위하여 각각의 보존제가 농도 별로 함유된 P. temperate M1021 균주의 동결건조 시료를 각 각 $0.1 \mathrm{~g}$ 씩 취하여 $10 \mathrm{~mL}$ 의 $0.85 \%$ 멸균 생리식염수에 완전히 현탁시킨 후, 동일한 식염수에 $10^{-1} \sim 10^{-6}$ 으로 희석하였다. 단계 별로 희석한 시료를 TSB agar plate에 $100 \mu \mathrm{L}$ 씩 도말한 다음 $28^{\circ} \mathrm{C}$ 에서 48 시간 배양하여 균 수를 측정하였다.

동결건조 처리 후 균의 저장성 조사. 동결건조 처리한 미생물 시료의 저장성을 알아보기 위하여 각 보존제의 첨가 농도별로 저장기간에 따른 생존율 변화를 측정하였다. $4^{\circ} \mathrm{C}$ 에서 2 주 간격 으로 8 주간 동안 측정하였으며, 동결건조 시료를 각각 $0.1 \mathrm{~g}$ 씩 취하여 $10 \mathrm{~mL}$ 의 멸균 생리식염수에 완전히 현탁시킨 후, 단계 별로 희석하여 $\mathrm{TSB}$ agar plate에 $100 \mu \mathrm{L}$ 씩 도말한 다음 $28^{\circ} \mathrm{C}$ 에서 48시간 동안 배양하여 균수를 측정하였다.

동결건조 처리 후 균의 살충력 조사. 균의 살충력 시험을 위하 여 각각의 동결건조 시료를 $0.1 \mathrm{~g} / \mathrm{mL}$ 로 제조한 다음 멸균생리 식염수를 이용하여 $10^{-1} \sim 10^{-4}$ 배로 희석하였다. 희석한 시료는 microsyringe를 이용하여 5령 이상의 꿀벌 부채명나방 유충의 혈체강(hemolymph)에 $3 \mu \mathrm{L}$ 씩 주사한 다음, 25 incubator에 보 관하면서 24 시간 간격으로 사멸율을 조사하였다. 각각의 실험 에서 유충은 10 마리씩 사용하였으며 모든실험은 3회 이상 반 복하여 수행하였다.

\section{결과 및 고찰}

동결에 따른 균의 생존율 변화. 동결건조 후의 생존율은 수차 례의 반복실험에서도 동일하게 $0.08-0.13 \%$ 로 극히 낮았다(Fig. 1).

동결건조 시 첨가된 보존제 종류에 따른 생존율 변화. 보호제 로 skim milk를 첨가한 경우 농도가 증가할수록 동결건조 시료 에서의 P. temperata M1021 균주의 생존율도 점차 증가하여 $7 \%(\mathrm{w} / \mathrm{v})$ 일때 가장 높은 $63 \%$ 의 생존율을 나타내었으나 $10 \%$ 이상에서는 생존율이 감소하였다(Fig. 1A). Starch와 sodium alginate는 미생물의 보존 및 캡슐화에 많이 사용되는 고분자 물 질로 알려져 있다. 본 실험에서는 starch의 첨가농도가 $5 \%(\mathrm{w} /$ v) 일때와 sodium alginate의 첨가농도가 $1.5 \%(\mathrm{w} / \mathrm{v})$ 일 때 각각 3.53 와 $3.4 \%$ 의 생존율을 나타내어 보존제를 첨가하지 않은 대 조군에 비하여 약 30배 이상의 보존효과를 나타내었으나 skim milk의 효과에 비해 상대적으로 크지 않았다(Fig. 1B-C). Sodium glutamate를 첨가한 경우에는 Fig. $1 \mathrm{D}$ 에서와 같이 동결건조에 따른 세포 보호효과가 전혀 나타나지 않았다. Glucose를 보호 제로 사용했을 경우 $1 \%(\mathrm{w} / \mathrm{v})$ 의 농도에서 $2.11 \%$ 의 생존율을 나타내는 보호효과가 있었으나, glucose가 $1.5 \%(\mathrm{w} / \mathrm{v})$ 이상 첨 가되었을 경우에는 동결건조 후 정상적인 분말을 형성하지 못 하는 단점이 있으므로 $1 \%(\mathrm{w} / \mathrm{v})$ 를 초과하는 농도에서는 실험 을 수행하지 못하였다. Sodium alginate가 세포의 생존율에는 크게 영향을 미치지 않았으나 주로 미생물의 캡슐화에 사용된 다는 점에 착안하여 sodium alginate $1.5 \%$ 및 skim milk $7 \%$ 를 혼합하여 보호효과의 상승을 기대하였으나 이러한 배합으로 는 오히려 생존율이 낮아지는 결과를 확인하였다(데이터 미제 시). 또한 일반적으로 미생물 보존 시에 사용하는 glycerol을 $25 \%(\mathrm{v} / \mathrm{v})$ 첨가하여 동일한 실험을 진행하였을 경우의 생존율 은 $73 \%$ 로 매우 좋게 나타났으나 점성이 지나치게 높아 동결건 조 후 분말형태로 가공할 수 없으므로 미생물 제제로 만들수 없었다(데이터 미제시).

저장기간에 따른 동결건조 균주의 안정성. 동결건조 직후의 생 균수를 $100 \%$ 로 할 때, skim milk가 첨가되지 않은 경우 2주 차의 시험에서 모두 사멸한 것으로 나타났다(Fig. 2). Skim milk의 농도를 5 및 $10 \%(\mathrm{w} / \mathrm{v})$ 첨가한 경우에는 동결건조 4 주 
A
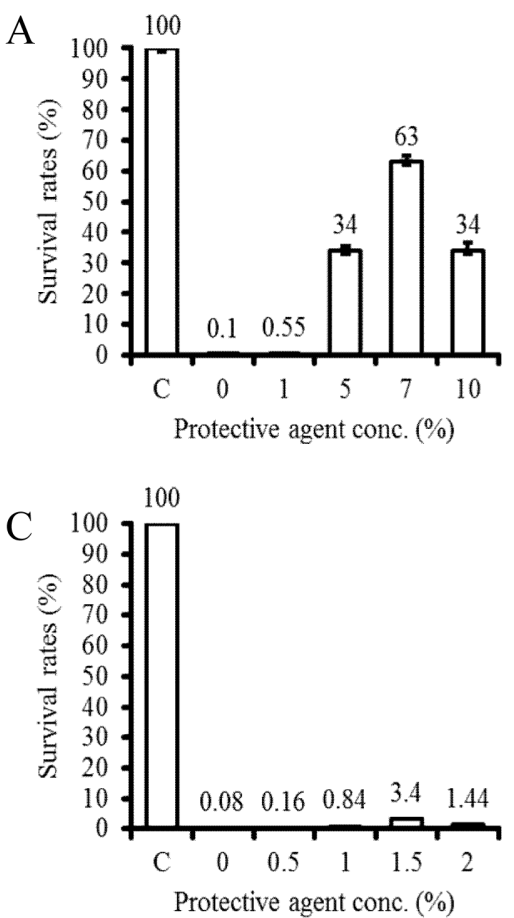

$\mathrm{B}$
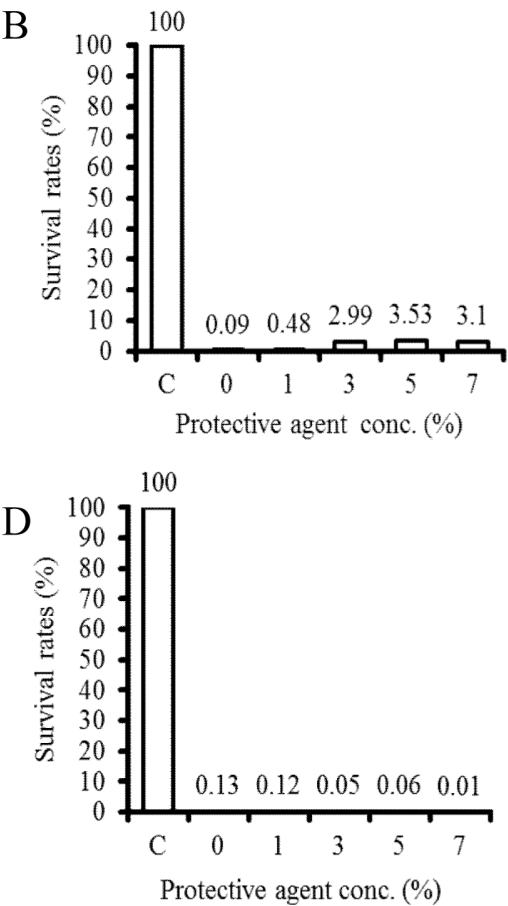

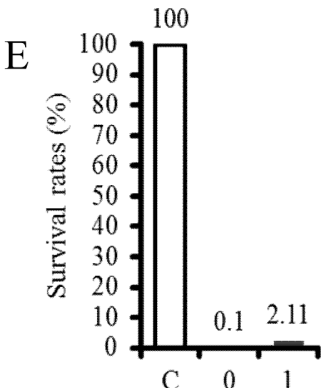

Protective agent conc. $(\%)$

Fig. 1 Comparative effect of different protective agents on Photorhabdus temperata strain M1021 after freeze-drying. P. temperate M1021, has been lyophilized via freeze-drying along with protective agents such as skim milk, starch, sodium alginate, glucose and sodium glutamate to protect cells from lysis. Percentage of survival rates of P. temperata M1021 with (A), skim milk; (B), starch; (C), sodium alginate; (D), sodium glutamate; (E), glucose. Error bars represent SD.

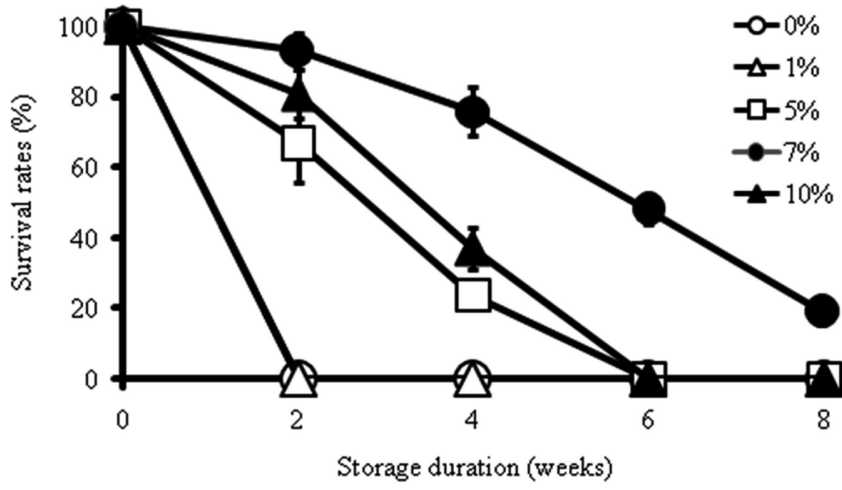

Fig. 2 Effects of skim milk (0-10\%) on viability of freeze dried powder of $P$. temperata strain M1021 stored at $4^{\circ} \mathrm{C}$. The skim milk was added to the concentrated cell suspension $(25 \times)$, finally $(\bigcirc), 0 \% ;(\triangle), 1 \% ;(\square)$, 5\%; $(\mathbf{O}), 7 \% ;(\boldsymbol{\Delta}), 10 \%$. Error bars represent SD.

후에 각각 24.38 와 $36.74 \%$ 의 생존율을 나타내었으나 6주 후에 는 거의 모든 균이 사멸하였다(Fig. 2). Skim milk를 7\% (w/v) 농도로 첨가한 시료는 P. temperata M1021 균주의 $75 \%$ 이상 이 저장 4 주 까지도 유지되는 것으로 나타났으며 6 주 및 8주 후에도 각각 $48,18.5 \%$ 의 생존율을 보였다(Fig. 2). 동결건조 균을 산소가 없이 포장하여 밀봉하고 저온에서 보관하였을 경 우에는 6 개월 후에도 $50 \%$ 이상의 생존율이 나타났다(데이터 미 제시).

P. temperata M1021 균주 동결건조 분말의 살충력 시험. $P$. temperata M1021 균주의 주사량이 $2.0 \times 10^{3}$ cells 이상일 때는

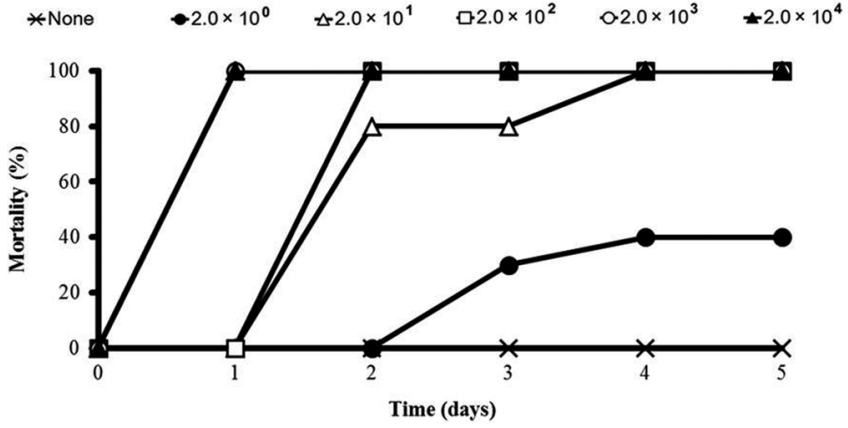

Fig. 3 Insecticidal effects of freeze dried P. temperata M1021 containing $7 \%$ skim milk on larvae of G. mellonella. Bacterial cell were injected at a concentration of $(\boldsymbol{\Delta}), 2.0 \times 10^{4} ;(\bigcirc), 2.0 \times 10^{3} ;(\square), 2.0 \times 10^{2} ;(\triangle)$, $2.0 \times 10^{1} ;(\mathbf{O}), 2.0 \times 10^{0}$ cells in $3 \mu \mathrm{L}$ of $0.85 \% \mathrm{NaCl}$ solution per larva for G. mellonella. $(\times)$, controls received the same quantities of sterile $\mathrm{NaCl}$ solution. Ten larvae of $G$. mellonella were inoculated for treatment.

주사 후 24 시간 이내에 모든 유충이 사멸 하였으며, $2.0 \times 10^{1}$ cells이 주사되었을 경우에도 유충의 $80 \%$ 가 2일 이내에 사멸하 는 것으로 나타났다(Fig. 3). 또한, $2.0 \times 10^{0}$ cells의 아주 낮은 농도에서도 유충의 $50 \%$ 가 주사 후 4 일만에 사멸하는것으로 보 아, 동결건조된 P. temperata M1021 균주가 꿀벌부채명 나방유 충의 혈체강 내에서 활발히 증식하여 독성을 나타내는 것으로 보인다.

오늘날 생물제제로 활발히 연구되고 있는 Pseudomonas fluorescens Pf-5와 P. fluorescens CHA0의 경우 3 cells/larva의 낮은 농도에서도 꿀벌 부채명나방 유충에 대한 사멸율이 

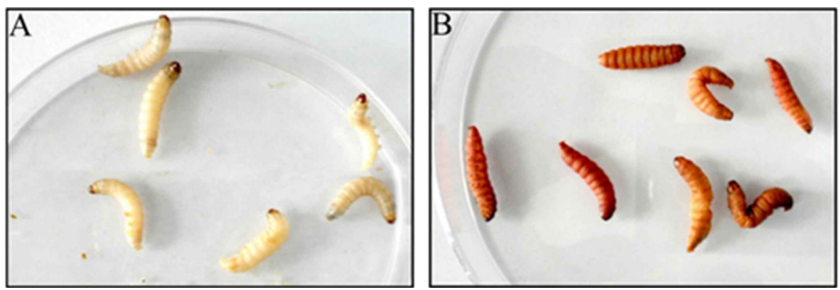

Fig. 4. Post injection morphological symptoms appeared in $G$. mellonella. (A), larvae injected with $0.85 \% \mathrm{NaCl}$ solution; (B), larvae injected with $2.02 \times 10^{2}$ cells of freeze dried $P$. temperata M1021 turned to brick red color.

10 65\%로 보고되고 있다(Baehler et al., 2005; Péchy-Tarr et al., 2008). 본 연구에서 사용된 P. temperata M1021 균주는 제 제화를 위한 동결건조 후 매우 낮은 농도에서도 유충에 대한 살충효과가 뛰어난 것으로 조사되었으며 이를 이용한 실질적 생 물학적 해충 방제제로의 개발가능성이 높을 것으로 기대된다. P. temperata M1021 균주에 의한 꿀벌 부채명나방 유충에 나 타나는 사체의 전형적인 양상은 Fig. 4에서와 같이 유충이 죽은 후 몸이 붉게 변하며 팽압을 상실하는데, 이것은 Photorhabdus 균주가 생산하는 anthraquinone 색소에 의한 것으로, P. luminescens 와 P. temperata 균주만의 특징이라 할 수 있다(Kuwata et al., 2008). 따라서 본 연구에서 사용된 동결건조 P. temperata $\mathrm{M} 1021$ 에 의한 주사독성의 발현은 오로지 동결건조된 살충균에 의한 효과로 확인되었다.

\section{초 록}

오늘날 환경친화적인 생물농약을 개발하기 위한 미생물로는 Bacillus thuringiensis 이외에 Photorhabdus, Xenorhabdus 및 Serratia와 같은 곤충병원성 미생물과 Pseudomonas와 같은 식 물유용 미생물에 대한 연구가 활발히 진행되고 있다. 본 연구 에서는 곤충병원성 미생물인 Photorhabdus temperata M1021 균주를 동결건조법을 이용하여 제제화 하였으며, 동결건조 시 세포보호를 위하여 skim milk, starch, sodium alginate, glucose 와 sodium glutamate를 농도별로 첨가하여 동결 건조 후의 세 포 생존율을 확인하였다. 그 결과 $7 \%(\mathrm{w} / \mathrm{v})$ 의 skim milk가 첨 가된 시료에서 가장 높은 $63 \%$ 의 생존율을 나타내었다. 제제화 된 동결 건조균을 공기와 접촉시키면서 저온에서 생존율을 측 정한 결과 4 주 후에도 $75 \%$ 이상의 생존율을 나타내었다. 또한 제제를 이용한 살충력 시험에서 꿀벌 부채명나방 유충에 대한 주사독성은 $2.0 \times 10^{1}$ cells/lavar 이상을 주사할 경우 4 일 이내에 전체유충이 사멸하는 것으로 나타났으며, $2.0 \times 10^{0}$ cells/larva의 아주 낮은 농도에서도 $50 \%$ 이상의 유충사멸 효과를 확인하였 다. 본 연구에서 사용된 P. temperata M1021 균주의 동결건조 분말의 뛰어난 살충효과는 보다 현실적인 생물학적 제제로의 개 발가능성을 제시하고 있다.

Keywords biopesticide $\cdot$ freeze-drying $\cdot$ Photorhabdus . skim milk

감사의글 이 논문은 2010 년도 정부의 재원으로 한국연구재단의 기초연구 사업(과제번호 2010-0009969)과 환경부의 “차세대 에코 이노베이션 사업”으
로 지원받은 연구이며, 연구비 지원에 감사드립니다.

\section{참고문헌}

Baehler E, Bottiglieri M, Pechy-Tarr M, Maurhofer M, and Keel C (2005) Use of green fluorescent protein-based reporters to monitor balanced production of antifungal compounds in the biocontrol agent Pseudomonas fluorescens CHA0. J Appl Microbiol 99, 24-38.

Bashan Y, Hernandez J-P, Leyva L, and Bacilio M (2002) Alginate microbeads as inoculant carriers for plant growth-promoting bacteria. Biol Fertil Soils 35, 359-68.

Blackburn MB, Domek JM, Gelman DB, and Hu JS (2005) The broadly insecticidal Photorhabdus luminescens toxin complex a (Tca): Activity against the Colorado potato beetle, Leptinotarsa decemlineata, and sweet potato whitefly, Bemisia tabaci. J Insect Sci 5, 32.

Bozolu TF, Özilgen M, and Bakir U (1987) Survival kinetics of lactic acid starter cultures during and after freeze drying. Enzym Microbial Technol 9, 531-7.

Brugirard-Ricaud K, Duchaud E, Givaudan A, Girard PA, Kunst F, Boemare $\mathrm{N}$ et al. (2005) Site-specific antiphagocytic function of the Photorhabdus luminescens type III secretion system during insect colonization. Cell Microbiol 7, 363-71.

Daborn PJ, Waterfield N, Silva CP, Au CPY, Sharma S, and ffrench-Constant RH (2002) A single Photorhabdus gene, makes caterpillars floppy (mcf), allows Escherichia coli to persist within and kill insects. Proceed Natl Acad Sci 99, 10742-7.

Dong Woon L, Ho Yul C, Ok Jin S, Jae Su Y, and Young Sub K (2002) Damage of perennial ryegrass Latium perenne by Chestnut Brown Chafer, Adoretus tenuimaculatus (Coleoptera: Scarabaeidae) and biological control with Korean isolate of entomopathogenic nematodes. Korean J Appl Entomol 41, 217-23.

Ehlers R-U (2001) Mass production of entomopathogenic nematodes for plant protection. Appl Microbiol Biotechnol 56, 623-33.

ffrench-Constant R and Bowent D (1999) Photorhabdus toxins: Novel biological insecticides. Curr Opin Microbiol 2, 284-8.

Ji D and Kim Y (2004) An entomopathogenic bacterium, Xenorhabdus nematophila, inhibits the expression of an antibacterial peptide, cecropin, of the beet armyworm, Spodoptera exigua. J Ins Physiol 50, 489-96.

Kaya HK, Aguillera MM, Alumai A, Choo HY, de la Torre M, Fodor A et al. (2006) Status of entomopathogenic nematodes and their symbiotic bacteria from selected countries or regions of the world. Biol Control 38, $134-55$.

Kaya HK and Gaugler R (1993) Entomopathogenic Nematodes. Ann Rev Entomology 38, 181-206.

Kuwata R, Yoshiga T, Yoshida M, and Kondo E (2008) Mutualistic association of Photorhabdus asymbiotica with Japanese heterorhabditid entomopathogenic nematodes. Microb Infect 10, 734-41.

Péchy-Tarr M, Bruck DJ, Maurhofer M, Fischer E, Vogne C, Henkels MD et al. (2008) Molecular analysis of a novel gene cluster encoding an insect toxin in plant-associated strains of Pseudomonas fluorescens. Environl Microbiol 10, 2368-86.

Power B, Liu X, Germaine KJ, Ryan D, Brazil D, and Dowling DN (2011) Alginate beads as a storage, delivery and containment system for genetically modified PCB degrader and PCB biosensor derivatives of Pseudomonas fluorescens F113. J Appl Microbiol 110, 1351-8.

Rajagopal R, Mohan S, and Bhatnagar RK (2006) Direct infection of Spodoptera litura by Photorhabdus luminescens encapsulated in alginate beads. J Invertebrate Pathol 93, 50-3.

Tao XQ, Lu GN, Liu JP, Li T, and Yang LN (2009) Rapid degradation of phenanthrene by using Sphingomonas sp. GY2B immobilized in calcium alginate gel beads. Int J Environ Res Public Health 6, 2470-80.

Theunissen JJ, Stolz E, and Michel MF (1993) The effects of medium and rate of freezing on the survival of chlamydias after lyophilization. $J$ Appl Bacteriol 75, 473-7.

Wang L, Li XF, Zhang J, Zhao JZ, Wu QJ, Xu B et al. (2007) Monitoring of resistance for the diamondback moth to Bacillus thuringiensis CrylAc 
and Cry 1 Ba toxins and a Bt commercial formulation. $J$ Appl Entomol 131, 441-6.

Wolfe J and Bryant G (1999) Freezing, drying, and/or vitrification of membrane- solute-water systems. Cryobiology 39, 103-29.

Zhao G and Zhang G (2005) Effect of protective agents, freezing temperature, rehydration media on viability of malolactic bacteria subjected to freezedrying. J Appl Microbiol 99, 333-8.

Zhao J-Z, Cao J, Li Y, Collins HL, Roush RT, and Earle ED (2003) Transgenic plants expressing two Bacillus thuringiensis toxins delay insect resistance evolution. Nat Biotechnol 21, 1493-7. 